\title{
О СИНТАКСИ СЛОЖЕНЕ РЕЧЕНИЦЕ - ПОЛА ВИЈЕКА НАКОН СТЕВАНОВИЋЕВОГ УЏБЕНИКА СИНТАКСЕ
}

\begin{abstract}
У раду се анализирају србистички и/или сербокроатистички приноси синтакси сложене реченице у времену од изласка Савременог српскохрватског језика II: Синтаксе Михаила Стевановића (1969). Показаће се које су се теоријске и емпиријске измјене догодиле у српској синтакси сложене реченице у том педесетогодишњем периоду. Рјешења из Стевановићевог уџбеника поредиће се, с једне стране с рјешењима која су нуђена у различитим научним србистичким синтаксичким студијама и монографијама, а с друге стране са рјешењима датим у најновијој синтакси сложене реченице П. Пипера и др. (2019).

Кључне ријечи: Михаило Стевановић, Предраг Пипер, независносложена реченица, зависносложена реченица, независни везници, зависни везници, класификација везника, идентификација типа реченице.
\end{abstract}

Синтакси сложене реченице до универзитетског уџбеника Савремени српскохрватски језик II М. Стевановића засигурно је не само од свих синтаксичких него и од свих граматичких (под)дисциплина у србистици и/или сербокроатистици поклањано најмање пажње. То бјелодано показује број радова о сложеној реченици објављених до 1969. године пописаних у библиографији српске синтаксе (Вићентић и др. 2004), а посебно у Библиографији српске синтаксе сложене реченице (Адамовић/Стојиљковић 2018: 701-753). Уз то, готово све те радове и сам Стевановић у свом уџбенику наводи и неријетко коментарише. Зато су у том Стевановићеву уџбенику на својеврстан начин (не)посредно представљени и сви резултати србистичке и/или сербокроатистичке синтаксе до 70-их година XX вијека.

Па шта нам то и како о сложеној реченици доноси Савремени српскохрватски језик II М. Стевановића?

*mkovacevic31@gmail.com 
М. Стевановић све сложене реченице према врсти синтаксичких односа у које ступају просте реченице дијели у двије групе: 1) независне или напоредне реченице (реченице у паратакси), и 2) зависне реченице (реченице у хипотакси). И једне и друге сматра семантички („по смислу”) зависним. Синтаксички су, међутим, само друге зависне, док су прве „самосталне, независне по синтаксичком односу" (Стевановић 1979: 777).

Управо због тога Стевановић класификацију независних реченица врши само „по смислу”, тј. значењу, дијелећи их у пет врста: саставне (копулативне), закључне (конклузивне), супротне (адверзативне) искључне (ексклузивне), раставне (дисјунктивне), у оквиру којих поткласификацију даје према везницима, констатујући да поједини независни везници не само да могу у одређеним контекстима везивати различите врсте независних реченица (везници $a$ и $n a$ - и супротне и саставне реченице) него могу бити у различитим контекстима везници и независних и зависних реченица (везници: док и те).

За разлику од независних реченица, које су семантички зависне а синтаксички независне, зависне реченице су и семантички и синтаксички зависне. „Права, синтаксичка зависност”, каже Стевановић, „не може [се] утврдити ни према спољним знацима везе, ни према њихову смислу, већ пре свега другог на основу њихових синтаксичких функција. Зависне се реченице употребљавају у служби било којег реченичног дела, али су основне њихове функције, чак и кад иначе врше службу којег главног дела реченице, увек функције одредбе или функције допуне. И несумњиво ће најтачнија дефиниција зависних реченица бити ако се о њима каже да су то увек одредбе или допуне реченица или појединих делова реченица од којих зависе. Зато је зависне реченице и потребно прво поделити на две категорије: на категорију допунских и категорију одредбених реченица" (Стевановић 1979: 819)ํ.

М. Стевановић, дакле, све зависносложене реченице најприје дијели према функционалном типу у двије врсте: у допунске реченице и у одредбене реченице. Свака од тих двију општих врста зависних реченица дијели се даље на низ подврста, односно конкретних врста зависних реченица. Тако под допунске реченице Стевановић подводи чак осам типова зависних реченица: 1) изричне (декларативне) реченице (825); 2) вољне (волунтативне) реченице $(832) ; 3)$ императивне зависне реченице $(834) ; 4)$ зависне жељне реченице (834); 5) реченице „посредног (индиректног) говора” (838); 6) реченице „непосредног (директног) говора” (838-839); 7) зависно-упитне реченице (841); и 8) намерне (финалне) реченице, које „су сличне изричним зависним реченицама, посебно модалним" (845).

Одредбене зависне реченице Стевановић такође дијели у осам врста, чији се поткласификациони опис по правилу врши према типу везивног елемента. Тако се све одредбене зависне реченице код Стевановића дијеле на: 1) односне (релативне) реченице, „које се односе на неко име у главној, односно управној реченици или на целу ту реченицу”, а везивни елементи су

\footnotetext{
${ }^{1}$ Сва истицања подвачењем или курзивно у овом и свим наредним цитатима у тексту су накнадна, тј. наша-М.К. А сви бројеви у загради иза цитата односе се на библиографску јединицу Стевановић (1979).
} 
им: релативне заменице и везник да $(850) ; 2)$ временске (темпоралне) реченице, чији су везници кад, пошто, док, чим, како, откад, откако, да, што, тек, а, где (869); 3) месне реченице, чији су везивни елементи где, где год, куда, камо, докле, одакле, и откуда (882); 4) поредбене и начинске реченице, које се деле на: а) начинске, односно поредбено-начинске, с везницима како, као да, као што, што, колико и уколико, б) праве поредбене, с везницима него и но, и в) „поредбене за изузетну неједнакост”, с везницима (a) камоли, (а) некмоли, (а) толи, (а) где(ли), те, куд, откуд (885); 5) узрочне (каузалне) реченице, с везивним елементима: јер, што, зато што, због тога што, услед тога што, захваљујући томе што, будући да, када, како, пошто, чим, док, пошто, да (890); 6) последичне (консекутивне) реченице, с везивним елементима да, те и како (898); 7) погодбене (кондиционалне) реченице, с везницима ако, ли, да, кад (902), и 8) допусне (концесивне или пермисивне) реченице, с везивним елементима: иако, мада, премда, ма, макар, ако, ако и, да и, па да, и да, па опет, колико (909).

Циљ овога нашега рада је да покаже који су теоријски и емпиријски резултати србистичке и/или сербокроатистичке синтаксе сложене реченице довели до промјене статуса (појединих типова) сложених реченица - како независносложених тако и зависносложених - у односу на статус какав оне имају у Савременом српскохрватском језику II М. Стевановића. То значи да се у анализи нећемо бавити србистичким и/или сербокроатистичким приносима који се тичу нових рјешења унутар неког врсно неспорног реченичног типа (нпр. семантичког подтипа узрочне, временске, саставне, или неке друге сложене реченице), него ћемо се искључиво бавити новим рјешењима која се тичу промјене синтаксичког и/или синтаксичко-семантичког статуса неког формалног типа (модела) независносложене или зависносложене реченице српскога језика, при чему ће се, логично, у разматрање укључити и критеријуми-разлози који су ту промјену условили. Притом ће се рјешења у Стевановићевом уџбенику, с једне стране, поредити са рјешењима која доносе различите научне србистичке и/или сербокроатистичке синтаксичке студије и монографије, а, с друге стране, са рјешењима која доноси најновија вишеауторска синтакса сложене реченице српског језика, израђена под редакцијом П. Пипера (Пипер и др. 2018)². Од свих „граматика” српскога и/ или српскохрватског језика за поређење је изабрана само наведена зато што је она најрецентнија, зато што је посвећена искључиво сложеној реченици, а и зато што је у њој на крају дата и Библиографија српске синтаксе сложене реченице (Адамовић/Стојиљковић 2018: 701-753), тако је логично претпоставити да су се аутори те синтаксе сложене реченице при њеној изради користили научним резултатима србистике и/или сербокроатистике из посљедњег педесетљећа, тј. послије појаве Стевановићеве синтаксе.

У том педесетогодишњем периоду - који раздваја Стевановићеву (1969) и Пиперову синтаксу сложене реченице у србистици и сербокроатистици одбрањен је већи број докторских дисертација, којима треба додати и неколико монографија које су за тему имале анализу одређених (под)типова

${ }^{2}$ Коју ћемо у тексту рада обиљежавати скраћеницом ССР. 
сложених реченица. Између њих само су двије посвећене независносложеним реченицама: једна градационим синтаксичким конструкцијама (Катнић Бакаршић 1996), а друга реченицама с везницима $u, n a, m e, a$, али, него (Чудомировић 2015). Много је већи број дисертација које су дијелом или цјелином посвећене одређеном (под)типу зависних реченица, какве су дисертације о узрочним конструкцијама (Ковачевић 1988), о посљедичним конструкцијама (Вукојевић 2008), о концесивним конструкцијама (Кубурић Мацура 2014), о поредбено-начинским конструкцијама (Николић 2017), као и монографија о начинским конструкцијама (Палић 2007). Њима треба додати и дисертације посвећене кондензацији зависних реченица (Радовановић 1977) и деривацији зависних реченица (Марић 2012). Већи број дисертација и/или монографија за предмет има појединачни (под)тип зависне реченице. Такве су дисертације о односној реченици с везником „што” (Рагуж 1994), о релативним реченицама са форичким супстантивним антецедентом (Русимовић 2014), као и монографија о релативним реченицама (Кордић 1995), потом дисертације о временским реченицама (Антонић 2001), о допунским реченицама (Ружић 2006) и о зависним реченицама са значењем степена (Николић 2014).

За нашу анализу (под)типова независних и зависних реченица од свих наведених вјероватно су значајније двије дисертације које за предмет имају најспорнија структурна и идентификациона питања сложене реченице, а то је дисертација о сложеним везницима у савременом српском језику (Ђуркин 2018) и дисертација о конкретизаторима везничког значења (Вукић 2015). Њима уз раме је и монографија о корелативним конструкцијама (Московљевић Поповић 2018), а помена је важна и монографија о корелативној синтакси Б. Тошовића (2001). Тим (не)дисертационим монографијама треба придружити неколико синтаксичких књига које су цјелином или дијелом посвећене сложеној реченици (као нпр. Ковачевић 1998, 2003, 2009, 2011, 2015, 2020; Прањковић 1993, 2001; Танасић 2012; Палић 2019), а у којима су, уз навођење јасних критеријума, оспорена многа рјешења из Стевановићеве универзитетске синтаксе сложене реченице.

Кад се резултати свих тих монографија, књига и радова упореде са резултатима Стевановићевог уџбеника, онда се на основу њих може закључити шта је оспорено, а шта и даље актуелно из Стевановићеве синтаксе, односно шта је од тих педесетогодишњих синтаксичких резултата остало непознато и/или непризнато у ССР (2018).

Стевановићева су тумачења доживјела највише „преправки” у погледу издвајања, и синтаксичког одређења везника независносложених и зависносложених реченица, а самим тим и одређења њиховог синтаксичко-семантичког статуса. Стевановић у својој синтакси уопште не говори о критеријумима разликовања како везника и невезничких ријечи тако ни независних и зависних везника. А те су разлике врло битне како за статус координираних и субординираних реченица тако и за статус појединих њихових типова (в. Прањковић 1980-1981: 151-163; Ковачевић 1998: 11-13; 2020а: 13-17)³. У

\footnotetext{
${ }^{3}$ Независни и зависни везници разликују се синтаксички прије свега што су независни везници везници и синтагми и реченица, а зависни само реченица. Независне синтагме су хо-
} 
српском језику потпуно су диференцирани независни и зависни везници. Из тога проистиче да не постоје хомоформни независни и зависни везници, односно да не постоји ниједан везник који би у једном контексту према наведеним критеријумима био независни, а у другом контексту - зависни.

Стевановић је, међутим, тврдио да су везници док и те и независни и зависни, с тим да је везник док везник саставних независних реченица и временских зависних реченица, а везник те саставних и посљедичних реченица. У литератури је критеријално доказано да се у свим реченицама којима се у литератури поткрепљује супротно значење везника док, везник док понаша попут свих зависних везника (не твори независне синтагме, припада структури клаузе испред које стоји, премјешта се заједно са клаузом у оквиру сложене реченице), тако да се реченице које су подвођене под супротне независне реченице не могу, како смо то и у посебном раду и показали (Ковачевић 1998: 151-157), сматрати независносложеним, већ зависносложеним, и то контрастним зависносложеним реченицама. Контрастно значење прикључује се тако „зависним” значењима везника док - временском, узрочном и условном (уп. и: Танасић 2012: 195-212). И за везник те је недвосмислено доказано да се „више уопће не употребљава као (прави) субординирани везник”, односно да је те само „копулативни везник који - као и други копулативни везници - може имати више значења" (Прањковић 1993: 81).

Међутим, та критеријална синтаксичка диференцијација независних и зависних везника остала је непозната ауторима ССР, у којој се везник док кад је ,значењски сличан везнику $a$ " сматра супротним везником, што се поткрепљује примјером: Његов отаи је адвокат, док је његова мајка учителица (Пипер и др. 2018: 72). Међутим, сам тип пермутације клауза и њеног везника у датом примјеру - Док је његова мајка учитељиияа, његов отаи је адвокат - више је него јасан показатељ да се овај везник не може сматрати независним. У овој синтакси се не само везник те него и везник $n a$, без икаквих научних упоришта, наводи као везник и саставних и посљедичних реченица, ${ }^{4}$ гдје се и за једну и за другу употребу везника каже да имају „узрочно-последично" значење. Саставне узрочно-посљедичне реченице поткрепљују се и примерима Нису радили много па се нису уморили; Придржавала се савета лекара, те је брзо оздравила, док се за потврду посљедичних зависних реченица наводе и примјери: Радио је читав дан без одмора, те је рано отишао на починак; Она данас није завршила све своје обавезе, па ће морати и сутра да дође на посао (Пипер и др. 2018: 44, 53, 447). Сви наве-

мофункционалне синтагме, искључујући предикат. Када су везници предикативних реченица, независни и зависни везници се разликују по свом структурно-синтаксичком статусу. Независни везник не припада структури ни једне од клауза, он је структурно аутономан, док је зависни везник увијек структурни дио зависне клаузе. Из тога проистиче да при промени мјеста клауза у сложеној реченици и зависни везник мијења мјесто, а независни не мијења (нпр. Марко студира медицину, а Јелена хемију. Јелена студира хемију, а Марко медицину. Запослићу се кад завршим студије. Кад завриим студије, запослићу се. (уп.: Ковачевић 2020б: 15).

${ }^{4}$ Невјероватно је да се везник па наводи чак и као везник допусних реченица, што се потврђује примјером: Валај, нећу, na сад иркао од глади! (Пипер и др. 2018: 469). Наведени пример заиста је пример допусне, али компримиране допусне реченице, с испуштеним везником макар: Валај, нећу, na макар сад иркао од глади! тако да у овој реченици па уопште нема улогу везника, него је интензификатор. 
дени примери су, примијене ли се на њих критеријуми синтаксичке диференцијације независних и зависних везника, недвосмислено примјери само независних саставних реченица.

Пошто код Стевановића не постоје егзактни критеријуми за разликовање везника - па били они прости или сложени - од невезничких лексема и израза, онога тренутка када су ти критеријуми васпостављени доведен је у питање статус појединих врста сложених реченица. То се прије свега односи на Стевановићеве независне искључне и закључне реченице. Доказано је да елементи који су проглашавани везницима тих реченица (само и једино за искључне, а дакле, према томе, зато и сл. за закључне) уопште нису везници него конкретизатори везничког значења, тако да су дате реченице само један од семантичких подтипова саставних (закључне) или супротних (искључне) реченице. Употријебљене само с тим конкретизаторима, без супротног или саставног везника испред њих, дате саставне и супротне реченице не припадају синдетским, него асиндетским независним саставним или супротним реченицама. (Ковачевић 1998: 36-41; Вукић 2015). А такав статус оне имају и у ССР (2018: 614-626). У тој синтакси конкретизатор је једно од основних синтаксичких средстава на основу кога се врши семантичка поткласификација независносложених реченица. Анализа „коришћења” конкретизатора у тој синтакси показује да нема јасног критеријума шта јесу а шта нису конкретизатори везничког значења (за што се конкретна потврда даје у Ковачевић 2020a: 281-302), и је ли релевантна њихова подјела на структурно обавезне (неиспустиве или неексплетивне) и структурно факултативне (испустиве или експлетивне). Зато није чудо што многи у тој синтакси наведени „конкретизатори” не испуњавају два нужна услова која једна језичка јединица мора задовољити да би била конкретизатор, а то су: „1. да клауза лијево од координатора (читава клауза, контекст или пресупозиција) има функцију антецедента, на који се упућује помоћу семантичког конкретизатора, и 2. да семантички конкретизатор као јединица која припада клаузи десно од координатора, односећи се на елемент из структуре клаузе лијево од координатора, читаву клаузу, контекст или пресупозицију - реферише на исти појам, тј. успоставља са њим однос семантичке кореференцијалности (Вукић 2015: 62).

Код Стевановића нема егзактних критеријума ни за разликовање независних и зависних везника, али ни за међусобно разликовање типова независних везника. То се најбоље види по везницима реченица које Стевановић одређује као „поредбене реченице за изузетну неједнакост”, а то су везници (a) камоли и (a) некмоли. Ти везници дијеле све синтаксичке особине независних везника, тако да не могу творити зависне реченице, него само независне конструкције (независне синтагме и независне реченице). Доказано је да реченице с тим везницима чине градационе као посебан тип независносложених реченица (Ковачевић 1998: 42-57; Катнић-Бакаршић 1996: 70-93). Градационе реченице не творе се, међутим, само тим везницима, него и корелативним везницима не само... него/но/ већ (н) и, док је реченице с тим везницима Стевановић сврстао у саставне. ${ }^{5}$ Тако је у градационе реченице

${ }^{5}$, „У саставне, а не у супротне, иду и реченице са сложеном спољном ознаком њихове везе [...] не само ...него и (или но и или већ и)" (Стевановић 1979: 793) . 
као посебну четврту врсту независносложених реченица ушао један формално-семантички подтип Стевановићевих зависних поредбених реченица, и један подтип Стевановићевих саставних реченица. Управо то уважава и ССР, гдје се, без навођења било каквих класификационих критеријума, све независносложене реченице дијеле у четири врсте. Тамо се, наиме, каже: „Врсте напоредносложених реченица су, традиционално, саставне, раставне и супротне. У савременој синтакси српског језика као посебна врста издвајају се и градацијске реченице” (Пипер и др. 2018:39). И управо „градацију” градационих реченица ССР тумачи на досад у славистици незабиљежен начин. Иако наводи да градацијске реченице „изражавају разлику у степену испољавања неког својства" (Пипер и др. 2018: 76), у градацијске реченице се убрајају и тзв. еквативне реченице које подразумијевају исти а не различит степен испољавања неког својства. А међу тим еквативним реченицама наводе се експланативне (објаснидбене) реченице с везницима то јест, односно, другим речима, друкчије речено, илити (в. Ковачевић 1998: 58-79) типа: Фасада је обновљена, то јест (односно /другим речима/ друкчије речено/ илити) враћен јој је првобитни облик. Те реченице немају ништа заједничко са градационим реченицама, па макар се сматрале само градационим реченицама у ширем смислу, јер ни градација у ширем смислу ни у једном од словенских језика, како је то показала М. Катнић-Бакаршић (1996: 70-76, 93-105), не подразумијева дати тип независних реченица. Тај тип је contradictio in adjecto самој градацији. И нису само те еквативно-експланативне реченице спорне у оквиру градационих реченица у ССР, него и оне које се називају симилативним градацијским реченицама (нпр.: Он је најзад привео студије крају, односно дипломирао је), које означавају сличност, чиме искључују нужну граматичку компоненту градирања (степеновања) квалитета или квантитета, а самим тим и припадност градационим реченицама. Но, ни тиме се не исцрпљују грешке у обради градационих реченица у ССР. У њој се, на примјер, као недвосмислен критеријум припадности градационим диферентивним реченицама узима присуство везничког израза не само... него/но/већ без провјере има ли он у свим контекстима вриједност корелативног везника. Та корелативна конструкција, наиме, није, како је у литератури већ показано, нужно у свим контекстима корелативни везник. Да би била корелативни везник, морају бити „нужно у обје клаузе предикати истородни (или одрични или потврдни)" (Ковачевић 1998: 53). Ако то није случај, реченица није градациона него супротна, јер је тада њен везник само него, но или већ. То је тип реченица „наглашено супротног значења са занијеканим предикатом у првој и потврдним у другој суреченици”, као нпр.: Не само да није дошао $к$ мени, него је отишао из града; Не само да није марљива, него је лијена. (Худечек/Вукојевић 2006: 136). А управо такве реченице се у ССР, због привида постојања градационог везника, проглашавају „корективним” градационим реченицама, као нпр.: Не само да их не награђују него/већ/но их опет кажюавају. А ако је уз супротне везнике него, но и већ употријебљен конкретизатор супротности напротив, супротно томе, обратно, такве реченице се у ССР проглашавају „градацијским реченицама највеће супротности”, као нпр.: Не само да их нису похвалили него су их, напротив, казнили. Да би погрешно 
одређење било доведено до краја, ССР ће и супротну асиндетску реченицу са конкретизатором напротив прогласити „градацијском реченицом са значењем највеће неједнакости”, јер у њој „напротив може преузети везничку функцију”: Није више болестан, напротив, здрав је. (Пипер и др. 2018: 84). А шта тек рећи за градационе реченице „екстензивног степеновања”, за које су као примјери наведене саставна реченица (отворене структуре) с везником нити: Нико о томе ништа не зна, нити је чуо, нити је видео, или са везничко конкретизаторским скупом а и: Сви је тамо знају, а и она свакога зна. (Пипер 2018: 85). Ови примјери су показатељ неразликовања поетске градације (градације као стилске фигуре) и синтаксичке градације (градације као синтаксичке категорије). Критеријуми који стоје у подлози ова два типа градације се искључују већ самим тим што реторичко-семантичка градација подразумијева најмање три члана градационог низа, док синтаксичка градација подразумијева само и једино „затворену, двочлану структуру градационог низа" (Катнић Бакаршић 1996: 24, 73).

Нису у Стевановићевој синтакси само некорелациони градациони везници $а$ камоли и/или а некмоли једини примјер неразликовања независних и зависних везника, нити су конкретизатори искључног и закључног значења једине јединице које су погрешно сматране везницима. Та бољка још је израженија у ССР. Тако Стевановић међу допусне „везничке скупове” убраја и $n a$ onem (Стевановић 1979: 914), истина не наводећи за њ примјер, а у питању је очито спој саставног везника и конкретизатора супротности у функцији везивања супротне реченице.

У вишеауторској Пиперовој синтакси много је више проблема са идентификацијом како самих везника, тако и њихове припадности независним или зависним. Тако се у потпоглављу супротних реченица насловљеном „Супротне реченице са искључним значењем” каже да реченице с „речцом само” типа Сви су били ту, само њега није било „имају значење изузетка ('Ty су били сви осим ґега'), које се назива ексцептивним” [sic!], с тим да се „значење изузетка изражава и реченицама с везничким изразима осим што, сем што, једино што, само што", као нпр.: Сви су били ту осим/сем/само/једино што юега није било. (Пипер и др. 2018: 74). Овдје је очигледно помијешано ексклузивно значење супротних независних реченица са ексцептивним значењем зависносложених ексцептивних реченица, јер ниједан од наведених сложених везника није независни. Наиме, ,ексклузивност се остварује само у координираним, а ексцептивност само у субординираним конструкцијама" (Ковачевић 1998: 203). Ексклузивне конструкције немају самосвојне везнике, него само конкретизаторе везничког значења који долазе уз супротне везнике, док ексцептивне зависне реченице имају већи број сложених везника, „а то су: осим што, осим да, сем ито, сем да, изузев ито, изузев да, до што, до да, осим ако, осим уколико, осим кад, сем ако, сем уколико, сем кад, изузев ако, изузев уколико, изузев кад (који сви у свим контекстима имају ексцептивно значење, тј. контекстуално су неусловљени ексцептивни везници), ван (тога) ито, ван (тога) да, изван (тога) ито, изван (тога) да, с тим што, с тим да, само што и једино што (који сви само дијелом своје употре- 
бе припадају ексцептивним везницима, тј. који су контекстуално условљени ексцептивни везници" (Ковачевић 1998: 222; уп. и Ђуркин 2018: 382).

И у Стевановићевој синтакси и у ССР везник било сврстан је у везнике раставних реченица. А тај везник, како је више пута у србистици и/или сербокроатистици показано (Ковачевић 2006: 332-360; Прањковић 2016: 149153: Палић 2019: 172-187), никад не твори независносложену реченицу, него се сусреће искључиво или као везник раставних независних синтагми или као везник при координацији субординације у вишеструкосложеној реченици. Томе је потврда и неграматички (иако тако није квалификован!) примјер „исконструисане” раставне реченице с везником било у ССР: *Било узми, било остави! (Пипер и др. 2018: 62). Као што везник било не може творити независне реченице, тако ни „везник” као не може творити зависне реченице. Kaо се као везник не наводи код Стевановића, али се као везник „поредбених реченица” наводи у ССР. Тамо се констатује да „поредбене клаузе које се у структуру основне реченице уводе везником као обично имају у предикату квалификативни презент, мада нису искључена ни друга глаголска времена" (Пипер и др. 2018: 396). Таква констатација није потврђена ниједним примјером с „везником” као, него су наведени само примјери са сложеним везницима као што и као да. Али се зато при говору о парцелисању поредбених реченица констатује да „поредбене реченице често могу бити парцелати”, па се за потврду наводе и сљедеће парцелисане „реченице”: Сунце пече неподношљиво. Као жеравица.; Стравичне су и непријатне. Као авети.” (Пипер и др. 2018: 417). Истакнути парцелати с „везником” као, будући непредикативне јединице, нису поредбене реченице, него њихови номинални кондензатори. А управо је то једна од основних функција ријечце, а не везника као 6 . Pијеч као, наиме, врло често „служи као средство номинализације исказа, односно као средство преобликовања вербалних конструкција у номиналне [као нпр.: Дјевојка пјева као славуj.] Таква би се честица могла назвати номинализатором или, евентуално, кондензатором" (Прањковић 2013: 218). Номинални кондензатори нису реченице јер су непредикатске јединице, из чега логично проистиче да не постоји реченични везник као, па сљедствено ни поредбене реченице с тим „везником”.

Лексема као није једина лексема која је без икаквих критеријума проглашена зависним везником у ССР. Таквих је случајева у овој синтакси доста, посебно у дијелу насловљеном „Реченице са клаузама категоријалног комплекса условљености: узрочним, посљедичним, циљним, погодбеним, допусним" (434-490). У том се дијелу не зна ни шта је везник ни шта је предлог, ни шта је прилог, ни шта је прилошки израз, а посебно се не зна шта су прости а шта сложени везници, нити шта улази а шта не улази у структуру везника, а самим тим ни шта су обавезне а шта факултативне компоненте везника. Тако Д. Војводић, који је аутор овог дијела синтаксе, као „везнике и везничке изразе” за „циљну условљеност” наводи: да, да (би/не би), како

\footnotetext{
${ }^{6}$, „...ријеч као треба описивати као честицу (а не ни као прилог, ни као везник, а поготово не као приједлог). Та честица може имати бар три у много чему различите функције” (Прањковић 2013: 218).
} 
(би/ не би), еда (би), не би ли, нека, ради (тога да /да би), само (зато, ради тога) да (би) (451), док „везницима и везничким изразима” за „допусну условљеност" сматра: иако, ако и, да и, ма (ко/како/колико/гдје/ита), мада, макар, па, па (ма и/макар), премда, без обзира на (то што), упркос (томе што) (Пипер и др. 2018: 451, 468). Зна се да су садржаји који се дају у загради при навођењу сложених термина или пак идиоматских израза (какви су нпр. фразеологизми) - увијек факултативни, јер дата јединица и без њих има исту функцију и значење. Ако ту законитост покушамо провјерити на напријед наведеним формама циљних и допусних „везничких израза” у ССР, долазимо до закључка да у саставу везника као факултативна компонента може бити и 3. л. аориста глагола бити, што значи, на примјер, да су варијанте везника да, како и еда и „везници” да би/не би, како би/ не би, еда (би). А то је више него апсурдно јер дио предиката нити је нити може бити компонента „везничког израза”. Осим тога наведено, научно једино могуће, „читање” правописно представљене везничке структуре нужно упућује на закључак да зависни везник може бити и сам предлог ради, на што упућује ортографска форма „везничког израза” ради (тога да /да би), затим сам предлог упркос, што потврђује ортографска форма „везничког израза” упркос (томе што), или пак сам предлошки израз без обзира на шта потврђује ортографски облик „везничког израза” без обзира на (то што). А предлози и предлошки изрази никад нити су могли нити могу бити везници или везнички изрази. Измишљајући непостојеће форме „везника”, дајући их у досад никад непримјењиваном правописном облику, аутор овог дијела ССР није ни споменуо, а камоли да је анализирао велики број сложених везника у оквиру сваке од категорија условљености (уп. Ђуркин 2018: 155-156, 227-231, 244, 280-281, 341-347).

Да овај аутор ССР није једини аутор који има и те каквих проблема с идентификацијом везника уопште, а посебно сложених везника, најбољи је показатељ ауторка дијела синтаксе „Реченице с временским клаузом”. У дијелу закључка тог поглавља који се тиче везника временске реченице каже се: „У стандардном српском језику временска клауза, у поређењу са свим другим зависним клаузама, укључује се у структуру основне (матричне) реченице највећим бројем различитих везника. Ако се узму у обзир све формаЛНе и семантичке варијанте има их Преко 60: КАД(А), ОД КАД(А), ОД ВРЕМЕНА КАД(А), РЕТКО КАД(А), ПОВРЕМЕНО КАД(А), ПОНЕКАД КАД(А), ЧЕСТО КАД(А), СКОРО УВЕК КАД(А), КАД(А) ГОД, УВЕК КАД(А), СВАКИ ПУТ КАД(А), САМО/ЈЕДИНО КАД(А), ОСИМ/СЕМ / ИЗУЗЕВ КАД(А), У СИТУАЦИЈИ / У СЛУЧАЈУ КАД(А), САМО / ЈЕДИНО У СИТУАЦИЈИ / У СЛУЧАЈУ КАД(А), ОСИМ/СЕМ / ИЗУЗЕВ У СИТУАЦИЈИ / У СЛУЧАЈУ КАД(А), (ЧАК) И КАД(А), ТЕК КАД(А), (У)МЕСТО КАД(А), КАД(А), [...] А, ДОК ${ }_{1}$, САМО / ЈЕДИНО ДОК ${ }_{1}$, ОСИМ/СЕМ / ИЗУЗЕВ ДОК ${ }_{1},(\mathrm{CВЕ)} \mathrm{ДОК} 2$ (НЕ), ДОК 2 ГОД (НЕ), САМО ДОК ${ }_{2} \mathrm{HЕ}$, ДОКЛЕ $_{2}$ (НЕ), ДОКЛЕ 2 ГОД, ПР(ИЈ)Е НЕГО ШТО (/ПР(ИЈ)Е НО ШТО / ПР(ИЈ)Е НЕГО), НЕПОСРЕДНО ПР(ИЈ)Е НЕГО ШТО, ПОШТО, НАКОН ШТО, ТЕК ПОШТО, ТЕК НАКОН ШТО, ЧИМ, ТЕК ШТО, САМО ШТО, КАКО, ОТКАКО. ПОД везником се овде, дакле, подразумева свака она форма којом се клауза уводи у структуру реченице, без обзира на њену структурну сложеност, порекло 
или функционалну поливалентност” (Пипер и др. 2018: 358). Ни по каквим критеријумима, осим критеријума „одокативности”, више од двије трећине наведених „везника” не може се сматрати везником, а посебно везником временске реченице. Чудо је да по одокативном (не)критеријуму ауторка није „идентификовала” још стотинак „временских везника”, јер ако је везник „увек кад” - зашто везник није „никад кад”, или ако је везник „од времена кад” - зашто није и „од доба/тренутка кад” или пак „у времену/добу кад” или пак „до времена кад” и сл.; ако је везник „у ситуацији кад” - зашто није „у околности(ма) кад”, или ако је везник „непосредно пре него што” - зашто није „управо пре него што”, ако је везник „сваки пут кад” - зашто није „покоји пут кад”, и могли бисмо тих „зашто” набрајати у недоглед. Само то је довољан показатељ да се при идентификацији ових „временских везника" ауторка овог дијела ССР није држала ниједног битног синтаксичког критеријума. А тих критеријума је више и они су по правилу и јасни и врло егзактни (в. Ђуркин 2018: 37).

Стевановићева синтакса и ССР - ако се Стевановићеве подврсте допунских реченица, искључујући намјерне, подведу под допунске реченице као јединствен тип - имају једнак број значењски диференцираних зависносложених реченица Уз релативне (односне) реченице наводи се још осам или девет значењских врста (зависно од тога да ли се као једна или двије врсте сматрају поредбене и начинске реченице) адвербијалних реченица: мјесне, временске, узрочне, посљедичне, финалне, поредбене и/или начинске, условне и допусне. На основу тога би се могло, погрешно, закључити да се у педесетогодишњем развоју србистичке и/или сербокроатистичке синтаксе није доводила у питање значењска типологија зависносложених реченица. Друкчије речено, да у тој типологији није било никаквих битнијих промјена у односу на пред-Стевановићеву и Стевановићеву класификацију зависносложених, посебно адвербијалних реченица.

Наиме, од појаве Стевановићеве синтаксе критеријално је издвојено и детаљно описано неколико типова (врста) зависносложених реченица које Стевановић не помиње или као посебне врсте или уопште. Међу тим типовима реченица најприје треба поменути зависне пропратнооколносне реченице, односно реченице са пропратнооколносном клаузом. Те реченице као кондензаторе реченичног значења најприје издваја М. Радовановић (1977: 94-100), наводећи да се оне, кад су зависне $\mathrm{e}^{7}$ у сложену реченицу уводе везником $a \partial a$ неријетко праћеним изразом при том као верификатором овога значења, као нпр.: Младић је, а да се при том није много чудио и запиткивао, примио ту неочекивану пажьу као наређење. У таквим реченицама „везнички елемент a да при том пружа и додатне информације о нереализовању предикације као потенцијалне пропратне околности у реализовању корелативне предикације, али и о супротности дате семантичке ситуације према очекиваној”

\footnotetext{
${ }^{7}$ Као и многа друга значења и пропратнооколносно значење се изражава и независним реченицама, и то саставним независним реченицама с везником $u$ и конкретизатором пропратнооколносног везничког значења при том, а кад су те реченице асиндетске само конкретизатором при том (уп. Радовановић 1977: 94-100).
} 
(Радовановић 1977: 96). У свим зависним реченицама са сложеним везником $a$ да (у коме је $a$ интензификатор а да везник) пропратнооколносно значење, и то значење „недостајуће пратеће околности”, увијек је примарно, с тим да „зависне клаузе с везником $a$ да уз примарно значење пратеће околности могу у одређеним лексичкосемантичким увјетима попримити и компоненте других значења, али оне при том не губе своје основно значење: оно само постаје усложњено допусним, погодбеним, начинским и др. значењима" (Палић 2007: 151). Зато је потпуно неоправдано, да не кажемо научно потпуно неутемељено, ове реченице сврставати у „начинско-околносне клаузе”, како је то урађено у ССР, и при томе их још потврђивати везничко-конкретизаторским скупом независне саставне реченице $u$ притом, уз коментар да се реченице с тим везничким скупом могу третирати и као зависне начинске и као независне ${ }^{8}$ (Пипер и др. 2018: 428), заборављајући да везник $и$ никад, ама баш никад, не може бити везник зависних реченица. Осим тога, неки од примјера наведени за потврду „начинско-околносне клаузе”, рецимо примјер Човек може веровати у Бога, а да не припада ниједној вероисповести -јасно показују да у њима уопште нема начина него је у првом плану допусно значење, што се види и по могућности замјене везника $a$ да везником $u$ ако, без промјене основног значења реченице: Човек може веровати у Бога, и ако / ако и не припада ниједној вероисповести. Зато је реченице са пропратнооколносним значењем требало обрадити као посебан тип зависних реченица, уз издвајање свих њихових семантичких подтипова унутар пропратнооколносног као доминантног значења.

Када је доказано да не постоје независне супротне реченице с везником док, него да свака употреба везника док подразумијева зависну реченицу, било је неопходно ријешити којој врсти припадају реченице које су сматране супротним реченицама с везником док, као нпр.: Моја торба је велика, док је юена торба мала. Након критеријалне синтаксичко-семантичке анализе статуса тих реченица издвојене су као синтаксички неспорне реченище са контрастном зависном клаузом (Ковачевић 1998: 151-157; Танасић 2012: 195-210). „Те клаузе имају и свој непредикативни функционални еквивалент међу члановима просте реченице, а то је или дативна синтагма с предлогом насупрот или генитивна синтагма с предлошким изразом за разлику од. И наведене синтагме и наведене док-клаузе као примарно имају контрастно значење и увијек врше функцију адвербијалне (прилошке) одредбе контраста, односно контрастне адвербијалне одредбе" (Ковачевић 1998: 157). Но, ни тих реченица нема као посебне врсте зависних реченица у ССР, него се оне и даље, истина успутно, помињу у оквиру независних супротних реченица.

У детаљној синтаксичко-семантичкој анализи ексклузивних и ексцептивних конструкција доказано је да су екслузивне констукције искључиво независне, а ексцептивне искључиво зависне (Ковачевић 1998: 203-222).

${ }^{8}, \ldots$... српском језику су и клаузе уведене везничком скупином $и$ притом честа средства изражавања пратеће околности. Везник $u$ који је део везничког израза ( и притом) сигнал је координираних напоредних конструкција, те се реченице уведене везником и притом могу посматрати и у том смеру" (Пипер и др. 2018: 428). 
Као зависне, ексцептивне конструкције могу бити реализоване или у форми зависних предлошко-падежних синтагми, најчешће с предлозима осим и сем и предлошким изразом изузев, или пак у форми зависне клаузе с великим бројем сложених ексцептивних везника, на које је указано већ у претходном дијелу текста. Ни ексцептивне зависне реченице, без обзира на то што се творе са више од двадесет сложених везника, од којих је већина једнозначно ексцептивна - нису у ССР описане као посебна врста зависних реченица, него су, како смо већ констатовали, погрешно сврстане у подврсту независних супротних реченица. Ни код Стевановића ни у ССР не спомињу се уопште неспорно постојеће зависне реченице за значењем експекиије (Ковачевић 1998: 141-150), а доказано је да је „значење експекције примарно значење зависносложених реченица с везницима умјесто да, умјесто што (којима су синонимне, али у употреби врло ријетко заступљене, форме мјесто да /што и намјесто да/ што)" (Ковачевић 1998: 150). Осим тога, у тим граматикама нема ни сложених реченица са спецификативним значењем (в. Ковачевић 1998: 158-168), које су, посебно у специјалним функционалним стиловима српског језика врло честе, и творе се са неколико по правилу једнозначних (контекстуално неусловљених) спецификативних сложених везника: „с тим што и с тим да; с напоменом/уз напомену да, с том разликом што/да, с изузетком да; при чему" (Ђуркин 2018: 397-398).

Све наведено показује да је у србистици и/или сербокроатистици од појаве Стевановићевог универзитетског уџбеника синтаксе, тј. у посљедњих 50 година, било врло значајних резултата у области сложене реченице, који су у многоме промијенили Стевановићеву „слику” синтаксе сложене реченице, али су, нажалост, у највећем броју случајева остали непознати или непризнати у најрецентнијој синтакси сложене реченице српскога језика П. Пипера и др., објављеној 49 година након изласка Стевановићеве синтаксе.

\section{ЛИТЕРАТУРА}

Адамовић/Стојиљковић 2018: Мирјана Адамовић, Вукашин Стојиљковић, Библиографија српске синтаксе сложене реченице, у: Предраг Пипер и др., Синтакса сложене реченице у савременом српском језику, у редакцији Предрага Пипера, Нови Сад: Матица српска; Београд: Институт за српски језик САНУ, 701-753.

Антонић 2001: Ivana Antonić, Vremenska rečenica, Novi Sad-Sremski Karlovci: Izdavačka knjižarnica Zorana Stojanovića.

Вићентић и др. 2004: Биљана Вићентић, Маријана Папрић, Драган Милојевић, Часлав Манчић, Грађа за библиографију српске синтаксе, II поправљено издање, Београд: Институт за српски језик САНУ.

Вукић 2015: Маја Вукић, Комбиновање везника и невезничких речи у савременом српском језику, необјављена докторска дисертација, одбрањена 2015. на Филозофском факултету Пале. 
Вукојевић 2008: Luka Vukojević, Izražavanje posljedičnih odnosa u hrvatskome standardnom jeziku, Zagreb: Institut za hrvatski jezik i jezikoslovlje.

Ђуркин 2018: Веселина Ђуркин, Сложени везници у српском језику (и њихова функционалностилска дистрибуција), Београд: Јасен.

Катнић Бакаршић 1996: Marina Katnić-Bakaršić, Gradacija (od figure do jezičke kategorije), Sarajevo: Međunarodni centar za mir.

Ковачевић 1988: Miloš Kovačević, Uzročno semantičko polje, Sarajevo: Svjetlost.

Ковачевић 1998: Милош Ковачевић, Синтакса сложене реченице у српском језику, Београд: Рашка школа; Србиње: СПКД „Просвјета”.

Ковачевић 2003: Милош Ковачевић, Граматичке и стилистичке теме, Бањалука: Књижевна задруга.

Ковачевић 2006: Милош Ковачевић, Отворена питања конструкција с везником БИЛО, Списи о стилу и језику, Бањалука: Књижевна задруга, $332-360$.

Ковачевић 2009: Милош Ковачевић, Огледи из српске синтаксе, Београд: Друштво за српски језик и књижевност Србије.

Ковачевић 2011: Милош Ковачевић, Граматичка питања српскога језика, Београд: Јасен.

Ковачевић 2015: Милош Ковачевић, О реченици и њеним члановима, Београд: Јасен.

Ковачевић 2020а: Милош Ковачевић, Кроз синтаксу српскога језика, Подгорица: Матица српска - Друштво чланова у Црној Гори.

Ковачевић 2020б: Милош Ковачевић, Типови и значења независносложених реченица, Кюижевност и језик, LXVII/1, 13-25.

Кордић 1995: Snježana Kordić, Relativna rečenica, Zagreb: Hrvatsko filološko društvo, Matica hrvatska.

Кубурић Мацура 2014: Мијана Кубурић Мацура, Систем концесивних синтаксичких јединица у савременом српском језику, Филозофски факултет Бања Лука, необјављена докторска дисертација.

Марић 2012: Биљана Марић, Синтаксичка деривација у савременом руском књижевном језику у поређењу са српским, Београд: Филолошки факултет.

Московљевић Поповић 2018: Јасмина Московљевић Поповић, Корелативне конструкиије: теоријске основе анализе, Београд: Филолошки факултет.

Николић 2014: Марина Николић, Категорија степена у српском језику: сложена реченица, Београд: Институт за српски језик САНУ.

Николић 2017: Милка Николић, Поредбено-начинске конструкиије у српском језику, Крагујевац: Филолошко-уметнички факултет.

Палић 2007: Ismail Palić, Sintaksa i semantika načina, Sarajevo: Booklin.

Палић 2019: Ismail Palić, Gramatika, semantika i pragmatika rečenice, Sarajevo: Institut za jezik.

Пипер и др. 2018: Предраг Пипер, Миливој Алановић, Слободан Павловић, Ивана Антонић, Марина Николић, Дојчил Војводић, Људмила Поповић, Срето Танасић, Биљана Марић, Синтакса сложене реченище у савреме- 
ном српском језику, у редакцији Предрага Пипера, Нови Сад: Матица српска; Београд: Институт за српски језик САНУ, 35-90.

Прањковић 1980-1981: Ivo Pranjković, O problemu razgraničenja koordinacije i subordinacije u hrvatskom književnom jeziku, Filologija, X, Zagreb, 151-163.

Прањковић 1986: Pranjković Ivo, Zavisne rečenice u hrvatskom ili srpskom jeziku - klasifikacione nedoumice, Научни састанак слависта у Вукове дане, 15/1, 57-65.

Прањковић 1993: Ivo Pranjković, Hrvatska skladnja. Rasprave iz sintakse hrvatskoga standardnog jezika, Zagreb: Hrvatska sveučilišna naklada.

Прањковић 2001: Ivo Pranjković, Druga hrvatska skladnja: Sintaktičke rasprave, Zagreb: Hrvatska sveučilišna naklada.

Прањковић 2013: Ivo Pranjković, Što je kao, Gramatička značenja, Zagreb: Matica hrvatska, 212-219.

Прањковић 2016: Ivo Pranjković, Rastavni veznik i habitualizator bilo, Gramatika u riječima i riječi u gramatici, Zagreb: Matica hrvatska, 149-153.

Радовановић 1977: Milorad Radovanović, Imenica u funkciji kondenzatora, Novi Sad: Matica srpska (Посебан отисак из Зборника Матице српске за филологију и лингвистику, књ. XX/1 и XX/2).

Рагуж 1994: Dragutin Raguž, Odnosne rečenice s veznikom ŠTO, Zagreb: Hrvatska sveučilišna naklada.

Ружић 2006: Владислава Ружић, Допунске реченице у савременом српском језику, Нови Сад: Матица српска.

Ружић 2010: Владислава Ружић, О класификацији зависних реченица у српском језику, Српски језик, XV, 105-119.

Русимовић 2014: Тања Русимовић, Релативне реченице са форичким суnстантивним антецедентом у савременом српском језику, Филолошко-уметнички факултет у Крагујевцу, необјављена докторска дисертација, Крагујевац.

Стевановић 1979: [ $\left.{ }^{1} 1969\right]$ Михаило Стевановић, Савремени српскохрватски језик (граматички системи и књижевнојезичка норма) II. Синтакса, III неизмењено издање, Београд: Научна књига.

Танасић 2012: Срето Танасић, Из синтаксе српске реченице, Београд: Београдска књига, Институт за српски језик САНУ.

Тошовић 2001: Branko Tošović, Korelaciona sintaksa, Graz: Institut für Slawistik der Karl-Franzens-Universität Graz.

Худечек/Вукојевић 2006: Lana Hudeček, Luka Vukojević, Ne samo... nego/već (i) ustrojstva, Rasprave: Časopis Instituta za hrvatski jezik i jezikoslovlje, knj. 32, Zagreb, 127-158.

Чудомировић 2015: Јован Чудомировић, Семантика и прагматика саставних одн. супротних напоредних везника $u$, па, те, а, али, него, Београд: Филолошки факултет, необјављена докторска дисертација. 


\section{Miloš Kovačević \\ ON THE SYNTAX OF A COMPLEX SENTENCE - HALF A CENTURY AFTER STEVANOVIĆ'S TEXTBOOK ON SYNTAX}

\section{Summary}

The paper analyzes the Serbian and / or Serbo-Croatian contributions of the syntax of a complex sentence in the period since the publication of the textbook Modern Serbo-Croatian Language II: Syntax by Mihailo Stevanović (1969). It is shown which theoretical and empirical changes took place in the Serbian syntax of complex sentences in that fifty-year period. The solutions from Stevanović's textbook are compared, on the one hand with the solutions offered in various scientific Serbistic syntactic studies and monographs, and on the other hand with the solutions given in the latest book on the syntax of the complex sentence by P. Pipera et al. (2019).

In that fifty-year period - which separates Stevanović's (1969) and Piper's syntax of complex sentences (2018) - a large number of doctoral dissertations were defended in Serbian and / or Serbo-Croatian studies, several monographs were written and a large number of scientific studies and reviews analyzed certain (sub)types of complex sentences. In these scientific papers, a large number of Stevanović's solutions on complex sentences were challenged and / or changed. The analysis conducted in this paper showed that these new scientific results in most cases remained unknown or unrecognized in the most recent book on the syntax of a complex sentence of the Serbian language - that of P. Piper et al. (2018).

Key words: Mihailo Stevanović, Predrag Piper, independent compound sentence, dependent compound sentence, independent conjunctions, dependent conjunctions, classification of conjunctions and sentences, sentence type identification 